\title{
CAUSES OF SCHOOL ABSENTEEISM: CONFLICT EXPERIENCES OF PUPILS OF THE CHILDREN SOCIALIZATION CENTRE
}

\author{
Gražina Čiuladienė \\ Mykolas Romeris University, Lithuania \\ Brigita Kairiené \\ Mykolas Romeris University, Lithuania \\ Vitalija Grigaitienè \\ Mykolas Romeris University, Lithuania
}

\begin{abstract}
Destructive conflicts between a pupil and a teacher are considered to be one of the main reasons for avoiding school. Inappropriately managed conflicts lead to negative attitudes toward teachers and a school, course fear of the school. As a result of avoiding comes decrease in academic achievements, deteriorating relationships, dropping out of school. Research conducted in Lithuania shows that conflicts are often resolved in violation of the students' rights and regardless of their interests; the applied forcing and avoiding strategies lead to conflict escalation as both the number of its participants and its objects increases, the actions of the conflict resolution process become more stringent. Therefore, the aim of the study is to reveal the courses of conflicts due to absenteeism.

Applied research method is interview; data analysis method is thematic content analysis. 4 students of Children Socialization Centre were interviewed to gain information on the causes of their school nonattendance. Research results show that 4 main types of reasons are to be identified such as learning difficulties; usage of alcohol and drug; rejection of help of specialists; influence of the authority of friends. The study emphasizes the importance of preventing the escalation of conflicts in schools, and provides insights into alternatives for their constructive management.
\end{abstract}

Keywords: school absenteeism, conflict, causes, Children Socialization Centre, pupil, Lithuania.

\section{Introduction}

A situation when a pupil avoids going to school, and teachers and parents make efforts to bring one back to class, has three signs of conflict (Wilmot \& Hocker, 2001): interdependent parties, collision, actions aimed at eliminating collision. An unresolved conflict over class absenteeism leads to a decline in performance, badly-damaged relationships, or even dropping out of school, which has a negative impact on both the life of a young person and the social and 
economic well-being of a country (crime, unskilled labour, low productivity, less taxes collected, increasing state support) (Žiulyte \& Pipko, 2008). On the other hand, conflicts experienced by pupils are considered to be one of the main factors of school absenteeism: destructive conflicts between pupils and teachers lead to pupils' negative attitudes towards the teacher(s), school, school fear, deterioration in learning outcomes, conflicting and destructive behaviour, bullying (e.g., Skalická, Belsky, Stenseng, \& Wichstrøm, 2015; Wang, Harrison, McLeod, Walker, \& Spilt, 2018).

Research shows that conflicts are resolved by violating the child's (pupil's) rights and regardless of one's interests, the applied strategies of struggle and avoidance lead to deepening of the conflict (Čiuladiene \& Kairienè, 2017; Čiuladienè \& Kairienè, 2018): the number of conflict objects increases (negative image of the teacher, grades as a tool of power), the number of participants increases (parents, support specialists, administration become involved), actions of the conflict resolution process become stricter - application of minimal and medium child care measures. It must be acknowledged that efforts aimed at eliminating the conflict over class absenteeism are not effective enough: education support specialists and the school's Child Welfare Commission have limited possibilities of helping, as they become involved when the escalation of the conflict is already highly advanced.

R. K. Brunson and J. Miller (2009) studied how conflicts are shaped by the school environment, how and when school conflicts develop and spread outside the school, and discovered that outside school grounds are not controlled by teachers, thus, conflicts unresolved in schools move outside their territories. In Lithuania, teacher-pupil conflicts due to class absenteeism have hardly been investigated at all. No research was found that would show the consequences of the failure to resolve a conflict and its further escalation, which are related to the application of sanctions to the child: separating the child from one's legal representatives and one's usual environment, and placing one in an isolated institution - Children Socialization Centre (further - ChSC). The aim of the research is to examine the reasons for not attending school by pupils' of the ChSC.

\section{Analysis of the Causes of Conflict as a Condition for Constructive Conflict Management}

Conflict is a natural phenomenon in the process of socialization that determines the growth of a personality (Erikson, 2004; Simmel, 2007; Piaget, 2011). However, only constructive conflicts are associated with the development of a personality, while destructive conflicts correlate with adolescents' delinquent behaviour, crime (Garrard \& Lipsey, 2007; Runions \& Shaw, 2013). Destructive 
school conflicts reduce a person's opportunities for education and learning, disrupt the smooth development of a person's positive socialization, can become a cause of a person's delinquent behaviour.

The difference between the constructive conflict resolution and the destructive one is in the perception of the object of the conflict (the problem is not identified vs. identified with the opponent), peculiarity of the process (dialogue vs. struggle, avoidance). The orientation of resolution efforts towards the satisfaction of participants' interests (needs) is another feature of constructive conflicts (in the case of destructive conflicts, positions are operated). Therefore, a constructive conflict resolution is scientifically and methodologically based efforts, manifested in the moral value to preserve dialogue and dignity of participants, in the knowledge of how to satisfy the needs of conflict participants without violating their rights, and in abilities to manage manifestations of destructive conflicts.

Efforts to understand the cause of a conflict are linked to the expectation of a constructive resolution: once the cause is eliminated, there will be no conflict. Scientific literature, however, presents a number of interpretations of the cause of a conflict. The works of some researchers emphasize the subjective onset of a conflict. The self-control of a person (Rupšienè, 2000), perception of a situation, management of emotions, one's arguments, determine preconditions for the occurrence of a conflict (Čiuladienè, 2013). Other researchers present the cause of the conflict as a combination of subjective and objective factors. Ch.W. Moore (2003) identified several groups of the causes of conflicts: structural conflict occurs due to destructive behaviour, unequal power, control, vaguely defined goals, unclear procedures; interest conflict is caused by the frustration of needs (interests show what is important and matters to the participant of the conflict, aspirations, aims, requirements and suggestions to others can be derived from them); the cause of data conflict is lack of information, inaccurate information, different understandings and interpretations of information; causes of relationship conflicts are related to strong emotions, misperceptions or stereotyping, poor communication or even lack of communication; value conflicts occur because of different criteria for assessing behaviour and ideas, different ways of living, ideology.

Research on conflicts in school reveals that they occur because of the behaviour of both pupil and teacher (Targamadzè, 2006; Petrulytè, 2012; AgolliNasufi \& Rada, 2015; Saiti, 2015; Čiuladienè \& Kairienė, 2017; Čiuladienė \& Kairienè, 2018). Conflicts in school arise when the pupil disregards the rules of conduct (for example, is late for lessons), does not perform one's duties and tries to talk one's way out and/or lie, disrespects the elders by refusing to do what one is told, not hearing the word "no". Conflicts arise when the teacher imposes 
excessive demands on pupils to master the materials that do not correspond to the pupil's abilities, vaguely, uninterestingly presents the material, makes mistakes in assessments (does not follow the principles), fails to properly resolve the conflict, does not take the pupil's rights, interests, abilities, and needs into account, criticizes the pupil's hairstyle, clothes.

According to H.D. Will and S. Ramdohr (2015), the cause of the conflict is like an iceberg - it is impossible to see it quickly, as only a small part is visible above the water surface, only its top. The cause of the conflict is largely invisible: feeling, needs, aspects of identity, values, misunderstandings and communication issues lie "underwater". However, its seeing/analysis leads to a constructive resolution of the conflict.

\section{Children Socialization Centre as a Conflict Management Tool}

ChSC is a specialized state institution assigned to general education schools, which implements medium child care measures, with the purpose of forming and establishing socially acceptable behaviour of children, increasing their psychological resilience to the harmful impact of the social environment, and helping regain learning motivation by providing them with education, educational support, social, health care and other services (Law of the Republic of Lithuania on the Minimal and Medium Care for Minors, 2017), i.e. ChSC are identified as a destructive conflict management tool. The medium child care measure is a measure during which a child is educated, cared for, provided with educational support, social, health care and other services at the ChSC (Law of the Republic of Lithuania on the Minimal and Medium Care for Minors, 2017). The main difference between the medium child care measure and the minimal one, is that the child is separated from one's legal representatives and is placed in a ChSC. The medium child care measure can be imposed on children who have reached the age of 14, and to younger children - only in exceptional cases.

The medium child care measure can be imposed on children: 1) who have committed a crime or an act having characteristics of a criminal offense, but it was not possible to apply criminal liability at the time the act was committed; 2) whose behaviour poses a real threat to their own or other people's life, health or property; 3) for whom the imposition of the minimal care measure did not lead to a positive change in the behaviour, except in cases when the minimal care measure was imposed only due to school absenteeism. Therefore, the medium measure is imposed for delinquent behaviour, which involves not only the provision of assistance and services to the child, but also the sanction of separating the child from one's legal representatives and one's usual environment and placing one in an isolated institution. 
It should also be noted that the minimal measure is imposed first, which means that if the minimal measure is effective, it is likely that the medium measure on the child will not need to be imposed. The minimal child care measures are those, in the course of which a child is provided with educational support, social, health care and other services without being separated or being separated from one's legal representatives as little as possible (Law on the Minimal and Medium Care for Minors). The imposition of the medium child care measure essentially means that the conflicts that led to the imposition of a minimal measure, are unresolved and continue to escalate.

The topic of the causes of conflicts in school and ways to resolve them does not lose relevance. The issue of conflicts in school and the analysis of delinquent behaviour is also linked to a phenomenon of great concern to the countries of the European Union - early school leaving, the reduction of which to less than $10 \%$ by 2020 is one of the targets of the "Europe 2020" Strategy of the European Union (Brunello \& Paola, 2014; Petruškevičiūtè, 2015).

\section{Methodology}

The methodological approach to qualitative research was chosen, children's experiences related to the cause for the occurrence of conflict, its escalation before being placed in the ChSC, are analysed. Research object is the experience of conflict situations in school of pupils of the ChSC.

The research used a data collection method - open interview. In conducting the interview, the researcher relies on a plan that includes only introductory and essential questions, presents the main topics for the interview without formulating specific questions that the researcher creates during the interview depending on its course, on the relationship between the researcher and the subject, or on the interview environment (Morkevičius, Teleišienè, \& Žvaliauskas, 2008). The research question: what are the causes of conflicts in school, which are related to school absenteeism, for the pupils of the ChSC? The duration of the interview was approximately $30 \mathrm{~min}$. With the consent of the subjects, the interviews were recorded on a dictaphone.

The method of qualitative content analysis (Žydžiūnaitė \& Sabaliauskas, 2017) was applied to analyse the data collected. The transcriptions of the interviews were read several times with the purpose to extract important statements that were directly related to the informant's experience. Those statements were then grouped and transformed into several categories and subcategories for reliable interpretation. The content analysis method allows the researcher to summarize large amounts of information, to combine research data into subcategories and categories, etc. according to the content and meaning, as 
well as to study the connections of various text elements both with each other and with the whole scope of information.

Interviews were conducted with 4 informants - learners of the ChSC. The size of the research sample was determined by the application of the information saturation method: when the information started to recur, there was no purpose in involving more research participants. The research was carried out in September, 2020.

In conducting qualitative research, ethical issues are especially relevant due to its specificity (small research sample, clear informant, etc.) (Rupšienè, 2013). The selection of informants was carried out on a voluntary, volitional and confidential basis. Subjects were able to withdraw at any time during the research. Subjects were informed about the possibility of getting acquainted with the generalized research results. Due to the fact that all research participants were minors, written consents of all legal representatives concerning their participation in the research were obtained. In accordance with the principle of confidentiality, all names of subjects were coded with numbers as [1], [2], [3], [4].

There are three ChSC in Lithuania. One of them is for girls and two of them are for boys. The study was conducted at the boys' ChSC, therefore the gender of the subjects - men. As mentioned above, the medium child care measure can be imposed on children who range from 14 to 18 years of age. Therefore, age of subjects was from 15 to 16 years. The general characteristics of the subjects indicated in their files regarding their placement in ChSC: all informants had special educational needs, addictions, and harmful habits. These are not selected criteria, just all subjects had these characteristics.

\section{Research Results}

The analysis of causes of conflicts in school, related to school absenteeism, of the learners of the ChSC, allowed to distinguish several groups of causes: difficulties in the learning process; use of alcohol and drugs; rejection of educational support; influence of the authority of friends.

The group of causes of difficulties in the learning process includes the following sub-categories: difficulties in completing tasks and lack of interest in learning. Research data show that subjects experienced difficulties in completing tasks, because they did not understand how to complete them: "I didn't work in class, because I didn't understand anything" [1], "when they give math tasks, I don't understand anything, what I have to do there, so I didn't do them" [2], "I didn't understand anything there" [4].

Another subcategory of the difficulties in the learning process group of causes, is the lack of interest in learning, which shows that subjects were not 
interested in school: "I didn't see anything interesting in school"[1], "because I didn't care about anything, it was really not interesting at home, in the classroom"[3], interest in learning disappeared when the form of learning changed: “when I started learning remotely, it wasn't interesting to me, I didn't connect to distant classes"[4]; or the presence and activities with friends overshadowed the interest in learning: "there was nothing interesting at home, in the classroom, anywhere, just with friends outside"[3]; lack of interest is also related to the lack of involvement in the learning process and the difficulties experienced: "but when I didn't understand anything, it wasn't interesting to me" [2].

Another group of causes for not attending school, use of alcohol and drugs, was divided into subcategories: inability to study due to consumption; inability to participate in the learning process due to aggression under the influence; nonattendance of school due to consumption/addiction. According to the subjects, the use of alcohol and drugs became an obstacle for them to study - they either went to school under the influence or were getting stoned at school, which led to being excluded: "if I smoked "weed", there were disputes right away" [1], "I went to school after smoking "weed" and smoked "weed" at school" [2], "I went to school after smoking "weed" or always drunk" [4], "a friend gave me to smoke some kind of tobacco out of a bottle, I immediately became very intoxicated [...], then the school called me an ambulance" [4]. Another sub-category of causes for school absenteeism is related to aggressive behaviour under the influence at school, when the subject interrupted the learning process and was excluded from the learning process that day: "then I become somewhat angry and can no longer control myself" [1], "[...] I flung a chair, I turned the tables over, once I even kicked out a door at school with my friend" [2], "when intoxicated I become so brave, I can do all kinds of nonsense, I could tell everybody to back off and I told that, I screw them, I could even break furniture and do something else, I also came to school in that state" [4]. Third group of causes use of alcohol and drugs is related to school absenteeism due to use/addiction: "basically, I spent time with friends, used psychotropic substances with them" [1], "I was bored at school, [...] we went to steal, drink, take drugs, smoke, "prank" others" [2], "I didn't care about anything at that time, I stole, used drugs, I didn't go to school" [3].

Another group of causes for not attending school, rejection of educational support was divided into two subcategories. The first is disregard for the obligation to see a specialist. The subjects claimed that they were obliged to see an education support specialist, but ignored the following obligation and refused support: "I had to see a psychologist, I also went to a social pedagogue, but I visited maybe twice" [1], "I had to see a psychologist, but I didn't go" [2], "I had to go to a psychologist, but I never went, I also had to see a psychiatrist, but I 
didn't" [3], "I was offered help in all schools, but I didn't need it" [4]. The second subcategory: denial of the problem, which explains the rejection of educational support: "I don't know, it's probably not about me, anyway I'm not aggressive, I'm even-tempered" [1], "I was offered drug treatment, but I'm not a drug addict" [4].

Another cause of school absenteeism is the influence of the authority of friends, which was divided into four subcategories. First: choice of friends: "all kinds of "bandits" visited that centre. When they were telling what they were doing, where they were going, sharing what they were stealing, how they are treating teachers, I always listened. I wanted to be like them, they seemed so "cool", maybe I admired them" [2], "I met a new friend, that friend didn't go to school, then we got together and both started skipping school" [3], "over time I told everything to my friend, and he tells me to go from there to the crisis centre, you don't have to do anything there, no homework, nothing" [4]. Second: accomplice in the commission of criminal offenses: "basically, I spent time with my friends, we committed crimes with them, stole, drank, then he offered me to sell to others" [1], "with those friends I started stealing" [2], "and with that friend I started stealing and committing other criminal offenses" [3]. Third: accomplice in smoking, drinking alcohol and taking drugs: "with that acquaintance, when I made friends, he offered me "weed", so first time, second time and I began smoking "weed" more and more" [1], "with those friends I started drinking, smoking, taking drugs" [2], "with that friend I started taking drugs, he got me used to that. He always had what to smoke, drink, and if there was no, we stole" [3], "I was taking with my friends again, drinking, I was with friends, didn't come home" [4]. Fourth: accomplice in mocking others: "prank other people" [2], "it was "wicked", we hang out together, we pranked together, we made fun of somebody together" [3].

\section{Discussion}

Class absenteeism in both Lithuanian (e.g., Rupšienè, 2000; Civinskas, Levickaitè, \& Tamutienè, 2006) and foreign (e.g., Birioukov, 2016; Balkis, 2018) scientific literature is described as a sensitive issue, a large share of research is oriented towards substantiating the negative consequences of the problem, as well as identifying factors. The aim of the following research - to examine the causes of school absenteeism - how they are seen by the learners of the ChSC, who have experienced conflicts due to non-attendance of school.

Destructive conflicts can be the cause and consequence of delinquent pupil behaviour (e.g., Skalická, Belsky, Stenseng \& Wichstrøm, 2015; Hendrickx, Mainhard, Boor-Klip, Cillessen, \& Brekelmans, 2016; Wang, Harrison, McLeod, 
Walker, \& Spilt, 2018). Lithuania has created a system of measures, which helps the child to overcome the established misbehaviour; the child may be subject to minimal care measures, and if the application of the mentioned measures does not help to achieve positive behavioural changes, a medium care measure may be applied - temporary placement of a child in a ChSC. On the other hand, it is important to know preconditions of conflict management in the previous stage why the pupil stops attending school.

Research data revealed the complexity of the causes of conflict - the results reflect all types of causes identified by Ch.W. Moore (2003). Moreover, the spiralling nature of the deepening of unresolved causes was highlighted. First conflicts with teachers occur because of the non-performance of tasks provided by teachers (structural cause), when a pupil lacks knowledge to complete them (data conflict), when the opportunity to satisfy the need for recognition is lost (interest conflict), the focus is on interest, and not on efforts, work (value conflict). Conflicts of another level arise when certain classes are missed/school is not attended on certain days. The causes are also complex: non-compliance with the rules of conduct - use of alcohol and drugs, aggressive behaviour (structural cause); friendship with peer-users (interest conflict - it is important to satisfy the need of belonging to a group, feel valued), increase in knowledge gaps (data conflict), courage and freedom are valued (disobedience to teachers) (value conflicts), teachers and classmates are insulted (relationship conflicts). The conflict escalates even more when school is "dropped out" of: the adolescent stops attending/learning, behaves delinquently (structural causes) in order to satisfy the established need for addiction, rejects help by focusing on the pleasure of intoxication (value conflict), ceases communication with teachers and parents (relationship conflict).

It can be seen that the influence of friends is a key factor that determined school absenteeism and, at the same time, involvement in delinquent activities, which ultimately led to subjects being placed in ChSC. The influence of friends was primarily determined by their authority, characterized by the use of alcohol and drugs, criminal activities, which impressed the subjects and thus attracted their attention. Acquaintance with friends and accomplice with them also led to the involvement in the use of alcohol and drugs that grew into addictions ("I began smoking "weed" more and more", "he got me used to that").

Were the actions of conflict resolution aimed at eliminating the causes of school absenteeism? The analysis of causes allows to make assumptions concerning the lack of constructive conflict resolution. To what extent was the aim to help overcome learning difficulties (by organizing consultations/providing tasks corresponding to skills/rethinking challenges of distance learning for a learner with learning gaps and difficulties)? It should be noted that all participants 
of the research had special educational needs, but did not talk about special support offered to them in performing tasks at school. Moreover, when asked about educational support offered to them at school, they mentioned a social pedagogue, a psychologist, but did not mention the support of the teacher in carrying out the tasks that they did not understand. The solution to the difficulties of the learning process experienced by the subjects depends on the exclusive competence of the school, which has possibilities of educational support that, if properly enabled, would possibly manage the problem of non-attendance of school. The identified causes for not attending school due to the use of alcohol and drugs show that the causes are becoming deeper and their solution requires the involvement of addiction specialists. The fact that subjects, who had started to use alcohol and drugs, still attended school, provides an opportunity for schools to initiate assistance to such pupils. It can be seen that schools where pupils were studying offered them support of a social pedagogue, psychologist, put effort into solving the problems of school absenteeism, but what raises concerns is the coercive way of providing help - as claimed by the subjects - "I had to", "had to" indicates a one-sided aid-imposing approach, according to which assistance, most likely, is going to be ignored or rejected. In addition, it was revealed that subjects did not acknowledge the problems of misconduct and accordingly did not accept help, which also shows that when solving the problem of school absenteeism, attention most probably was not paid to identifying the problem itself, without which any efforts to help are meaningless. Thus, it becomes clear that conflict resolution in schools lacks a model for eliminating causes - no attention is paid to the intervention and post-intervention in a constructive conflict.

In order to constructively resolve a conflict and prevent its escalation, it is necessary to choose conflict resolution methods that correlate with its causes. Lack of timely efforts (oriented towards eliminating the causes) may necessitate the application of minimal or even medium child care measures. The following research emphasizes the importance of preventing the escalation of conflicts in school, provides insights into alternatives for their constructive management.

\section{References}

Agolli-Nasufi, I., \& Rada, A. (2015). Teachers' Experience and Perceptions on Conflicts at Schools: Their Solution and Addressing. Journal of Educational and Social Research, 5(2), 69-72. DOI: 10.5901/jesr.2015.v5n2p69

Balkis, M. (2018). Academic amotivation and intention to school dropout: the mediation role of academic achievement and absenteeism. Asia Pacific Journal of Education, 38(2), 257270. DOI: 10.1080/02188791.2018.1460258

Birioukov, A. (2016). Beyond the excused/unexcused absence binary: classifying absenteeism through a voluntary/involuntary absence framework. Educational Review, 68(3), 340-357. DOI: 10.1080/00131911.2015.1090400 
Brunello, G., \& Paola, M.D. (2014). The costs of early school leaving in Europe. IZA J Labor Policy, 3, 22. DOI: 10.1186/2193-9004-3-22

Brunson, R.K, \& Miller, J. (2009). Schools, Neighborhoods, and Adolescent Conflicts: A Situational Examination of Reciprocal Dynamics. Justice Quarterly, 26(2), 183-210. DOI: $10.1080 / 07418820802245060$

Civinskas, R., Balkis, V., \& Tamutienė I. (2006). Vengiančiu lankyti mokykla vaiku problemos ir poreikiai. Vilnius: Garnelis.

Čiuladienè, G. (2013). Paauglių konfliktai ir jų sprendimas ugdymo realybëje. Vilnius: Mykolo Romerio universitetas.

Čiuladienè, G., \& Kairienè, B. (2017). The resolution of conflict between teacher and student: students' narratives. Journal of teacher education for sustainability, 19 (2). 107-120. DOI: 10.1515/jtes-2017-0017

Čiuladienè, G., \& Kairienè, B. (2018). The resolution of conflict between teacher and student: teachers' narratives. In Society, Integration, Education: Proceedings of the International Scientific Conference, May 25th -26th, 3, 235-245. DOI: 10.17770/sie2018vol1.3249

Erikson, E.H. (2004). Vaikyste ir visuomene. Vilnius: Kataliku pasaulio leidiniai.

Garrard, W.M., and Lipsey, M.W. (2007). Conflict resolution education and antisocial behavior in U.S. schools: a meta-analysis. Conflict Resolution Quarterly, 25(1). 9-38. DOI: $10.1002 /$ crq.188

Hendrickx, M., Mainhard, M.T., Boor-Klip, H.J., Cillessen, A.H.M., \& Brekelmans, M. (2016). Social dynamics in the classroom: Teacher support and conflict and the peer ecology. Teaching and Teacher Education, 53, 30-40. DOI: 10.1016/j.tate.2015.10.004

Law of the Republic of Lithuania on the Minimal and Medium Care for Minors. (2017). Register or Acts, 2020-10-07, No. 20886, September 24, 2020.

Moore, Ch. W. (2003). The mediation process: practical strategies for resolving conflict. San Francisco: Jossey-Bass Publishers.

Morkevičius, V., Telešienè, A., \& Žvaliauskas, G. (2008). Kompiuterizuota kokybiniu duomenu analize su NVivo ir Text Analysis Suite. Kaunas: Kauno technologijos universitetas.

Petrulytè, A. (2012). Paauglio psichosocialine raida. Vilnius: Edukologija.

Piaget, J. (2011). Vaiko pasaulèvoka. Vilnius: Žara.

Petruškevičiūtè, A. (2015). Edukacinès sąveikos pokyčiai produktyviojo mokymosi sąlygomis. Pedagogika: mokslo darbai, 120(4), 42-60.

Runions, K.C., \& Shaw, T. (2013). Teacher-child relationship, child withdrawal and aggression in the development of peer victimization. Journal of Applied Developmental Psychology, 34, 319-327. DOI: 10.1016/j.appdev.2013.09.002

Rupšienè, L. (2000). Nenoras mokytis - socialinis pedagoginis reiškinys. Klaipėda: KUL.

Rupšienė, L. (2013). Rinktiniai edukologiniai raštai. Edukologinis tyrimas: sistema ir procesas; Ugdymo tyrimu idejos ir problemos. Vilnius: Lietuvos edukologijos universiteto leidykla.

Saiti, A. (2015). Conflicts in schools, conflict management styles and the role of the school leader: A study of Greek primary school educators. Educational Management Administration \& Leadership, 43(4), 582-609. DOI: 10.1177/1741143214523007

Simmel, G. (2007). Sociologija ir kultūros filosofija. Vilnius: Margi raštai.

Skalická, V., Belsky, J., Stenseng, F., \& Wichstrøm, L. (2015). Reciprocal Relations Between Student-Teacher Relationship and Children's Behavioral Problems: Moderation by Child-Care Group Size. Child Development, 86(5), 1557-1570. DOI: 10.1111/ cdev.12400 
Čiuladiene et al., 2021. Causes of School Absenteeism: Conflict Experiences of Pupils of the Children Socialization Centre

Targamadzè, V. (2006). Konfliktu kontūru brëžimas: ugdymo realybès kontekstas. Vilnius: Vilniaus pedagoginis universitetas.

Žiulytė, R., \& Pipko, J. (2008). Ties nesékmès riba. Vilnius: VIA Recta, 2008.

Žydžiūnaitè, V., \& Sabaliauskas, S. (2017). Kokybiniai tyrimai, principai ir metodai. Vilnius: Vaga.

Wang, C., Harrison, L.J., McLeod, Sh., Walker, S., \& Spilt J.L. (2018). Can teacher-child relationships support human rights to freedom of opinion and expression, education and participation? International Journal of Speech-Language Pathology, 20(1), 133-141. DOI: 10.1080/17549507.2018.1408855

Will, H.D., \& Ramdohr, S. (2015). Mediacijos vadovas socialiniams pedagogams. Vilnius: Všl „Pagalbos paaugliams iniciatyva ${ }^{e c}$.

Wilmot, W., \& Hocker, J. (2001). Interpersonal Conflict. New York: McGrawHill. 